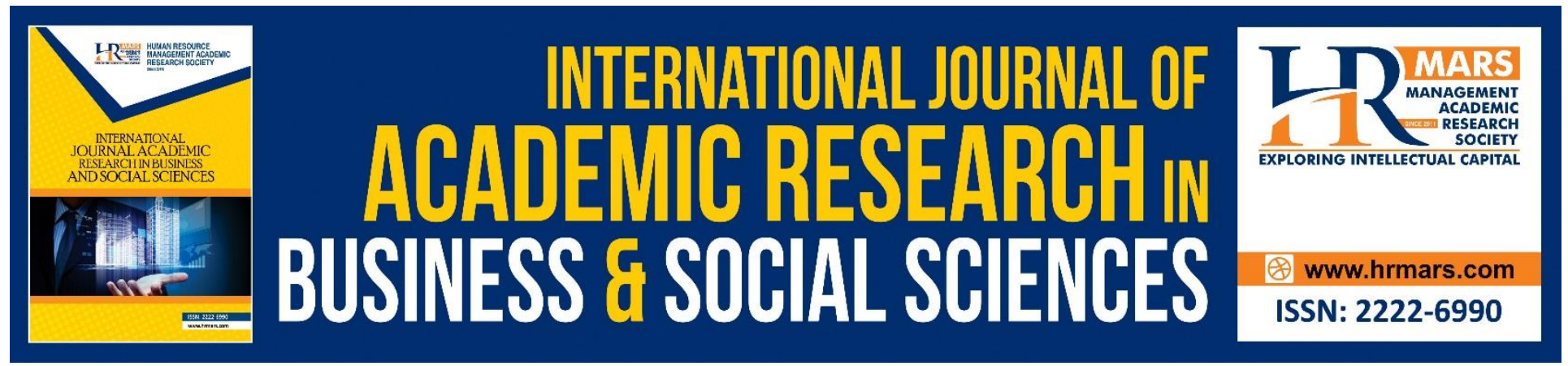

\title{
A Conceptual Framework of Factors Influencing Prevention- Related Practice Behaviors towards Non-Communicable Diseases (NCDs) of Low-Income Workers
}

\begin{abstract}
Azrin Shah Bin Abu Bakar, Haliza Abdul Rahman, Hayati Kadir Shahar, Ahmad Iqmer Nashriq Mohd Nazan, Khairuddin Idris
\end{abstract}

To Link this Article: http://dx.doi.org/10.6007/IJARBSS/v10-i16/8290

DOI:10.6007/IJARBSS/v10-i16/8290

Received: 07 October 2020, Revised: 22 October 2020, Accepted: 10 November 2020

Published Online: 24 November 2020

In-Text Citation: (Bakar et al., 2020)

To Cite this Article: Bakar, A. S. B. A., Rahman, H. A., Shahar, H. K., Nazan, A. I. N. M., \& Idris, K. (2020). A Conceptual Framework of Factors Influencing Prevention-Related Practice Behaviors towards NonCommunicable Diseases (NCDs) of Low-Income Workers. International Journal of Academic Research in Business and Social Sciences, 10(16), 27-40.

Copyright: (c) 2020 The Author(s)

Published by Human Resource Management Academic Research Society (www.hrmars.com) This article is published under the Creative Commons Attribution (CC BY 4.0) license. Anyone may reproduce, distribute, translate and create derivative works of this article (for both commercial and non-commercial purposes), subject to full attribution to the original publication and authors. The full terms of this license may be seen at: http://creativecommons.org/licences/by/4.0/legalcode

Special Issue: Youth and Community Wellbeing: Issues, Challenges and Opportunities for Empowerment V2, $2020, \mathrm{Pg} .27$ - 40 http://hrmars.com/index.php/pages/detail/IJARBSS JOURNAL HOMEPAGE

Full Terms \& Conditions of access and use can be found at http://hrmars.com/index.php/pages/detail/publication-ethics 


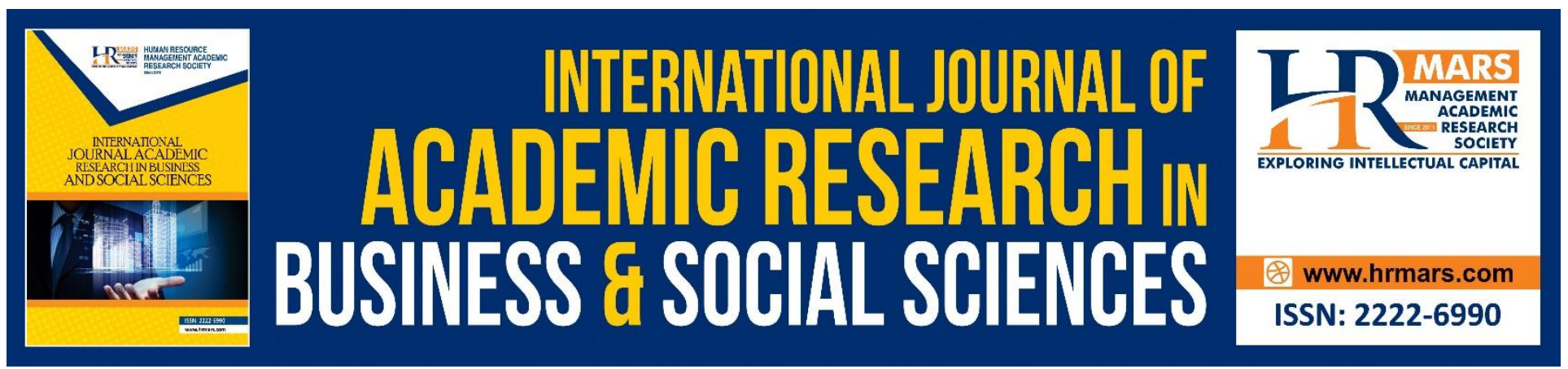

\title{
A Conceptual Framework of Factors Influencing Prevention-Related Practice Behaviors towards Non- Communicable Diseases (NCDs) of Low-Income Workers
}

\author{
Azrin Shah Bin Abu Bakar ${ }^{1}$, Haliza Abdul Rahman ${ }^{1,2}$, Hayati Kadir \\ Shahar ${ }^{3,4}$, Ahmad lqmer Nashriq Mohd Nazan ${ }^{3}$, Khairuddin Idris ${ }^{1}$ \\ ${ }^{1}$ Institute for Social Science Studies, Universiti Putra Malaysia (UPM), Serdang, 43400, Selangor \\ Darul Ehsan, Malaysia, ${ }^{2}$ Department of Environmental and Occupational Health, Universiti Putra \\ Malaysia (UPM), Serdang, 43400, Selangor Darul Ehsan, Malaysia, ${ }^{3}$ Department of Community \\ Health, Faculty of Medicine and Health Sciences, Universiti Putra Malaysia, 43400 UPM Serdang, \\ Selangor, Malaysia, ${ }^{4}$ Malaysian Research Institute on Ageing (MyAgeing ${ }^{\mathrm{TM}}$ ), Universiti Putra \\ Malaysia, 43400 UPM Serdang, Selangor, Malaysia. \\ Email: azrinshah4141209@gmail.com,dr.haliza@upm.edu.my, hayatik@upm.edu.my, \\ iqmernashriq@upm.edu.my, kidin@upm.edu.my
}

\begin{abstract}
This article proposes a conceptual framework of factors influencing prevention-related practice behaviors towards non-communicable diseases (NCDs) of low-income workers. The author adopted the Social-Ecological Model as a potential predictor of practice behaviors of employees related to the prevention of NCD. This article found five factors which are intrapersonal factor, interpersonal factor, organizational factor, community factor and societal factor and attitude as a mediating variables. This article suggests that these factors to be considered in future theoretical framework development on preventive practices towards NCD among low-income workers.
\end{abstract}

Keywords: Prevention-Related Practice Behaviors Factors, NCDs, Low-Income Workers.

\section{Introduction}

Health is an element that cannot be separated from the development of a country. Although Malaysia has developed and grown rapidly, health and the process of modernisation should go hand in hand without affecting or having a side effect on the well-being and prosperity of the people. Nevertheless, the impact of accelerated industrial development and urbanisation in recent decades has changed the pattern of employment, social and lifestyle have affected the health resulting in increased rate of chronic diseases. This trend led to morbidity and mortality in Malaysia. The noncommunicable diseases (NCDs) also known as chronic diseases is one of the leading causes of death among adults in Malaysia, which has resulted in high emotional and financial stress on individuals, 
families and countries. Moreover, this impact is felt especially by low-income residents to manage treatment, care and health with limited sources of income.

Past studies have revealed that the low-income group is more likely to engage in unhealthy behaviours, lack of social protection and lack of access to good healthcare, exposing them to high risk of NCDs, disability and death (Stringhini et al., 2017; Rockefeller Institute, 2013; Wilkinson, 2007). In addition, low-income workers also face dangers both in the workplace and in their communities. Grosch, Alterman, Petersen and Murphy (1988) explained that compared to other workers, low-income workers face more dangerous physical and psychosocial workplace exposure and less access to health promotion programs at their workplace. For a large number of low-income workers, employment is the only major source of income for them, which causes all decisions on personal and family health to depend on the source, influencing them not to take any leave from work when sick due to fear of losing wages that can affect occupational health and productivity (Robert Wood Johnson Foundation Commission to Build a Healthier America, 2009).

In Malaysia, it has been shown that the population of this country is composed of (B40), (M40) and (T20) groups, which each represents the lowest $40 \%$, middle $40 \%$ and the highest income group $20 \%$ (Mansor, Kassim \& Jawi, 2020; lordanides et al., 2014). Therefore, the low-income workforce forms a large part of the workforce in the country, which plays an important role in helping the management to streamline daily tasks and improve the quality of their services to achieve the development and economic agenda of the country. Nevertheless, studies have found that lowincome workers have been exposed to NCDs such as cardiovascular disease, obesity and mental illness (Othman et al., 2020; Chan et al. 2019; Fiidow, Huda \& Salmiah, 2016; Eng, Moy \& Bulgiba,2016; Sherina et al., 2011). This may be because the work environment has an influence on their behaviour and health outcomes.

In response to these issues, prevention-related practice behaviors play an important role for maintaining health and quality of life. This is in line with the 2030 agenda for Sustainable Development Goals (SDGs) especially on cores such as poverty (SDG1), health \& well-being (SDG3) as well as education (SDG4) for a sustainable development. Hence, this study aims to develop a conceptual framework on the determinants of preventive-related practice health behaviors among the low- income workers in the Malaysian.

\section{Literature Review}

\section{Prevention-related Practice Behaviors}

According to Lee, Park and Lee (2020), behavioural practices have a positive effect on an individual's physical health or ability to recover from illness. Van et al. (2007) and Twardella et al. (2006) reported that those with heart disease and stroke are more likely to quit smoking as well as improve exercise for health to reduce the risk of diseases. Meanwhile, individuals diagnosed with serious health conditions are more likely to behave to quit smoking than those who have not been diagnosed with the disease (Keenan, 2009). 
INTERNATIONAL JOURNAL OF ACADEMIC RESEARCH IN BUSINESS AND SOCIAL SCIENCES

Vol. 10, No. 16, Youth and Community Wellbeing: Issues, Challenges and Opportunities for Empowerment V2. 2020, E-ISSN: 2222-6990 @ 2020 HRMARS

In another study by Yamada, Hapsari and Matsuo (2020) reported that behaviours toward NCD prevention such as eating behaviour, physical activity, sleep and health check-ups had a significant correlation with physical health status $(p<0.05)$. This is also supported by Ozminkowski et al. (2006) where healthy behaviours such as a rich diet of fruits and vegetables and regular physical activity can prevent or delay the onset and progression of chronic diseases. In addition, a study on health information seeking behaviour among urban and rural Malay population showed that the majority of respondents tend to seek medical treatment by seeing a doctor (Rani et al., 2019). Similarly, in another study by Amal, Paramesarvathy, Tee, Gurpreet and Karuthan (2006) found that the Malay (65.8\%), India (61.2\%) and Chinese (45.8\%) population use the services of government health facilities for medical treatment and their diseases.

\section{Socio-Ecological Model (SEM) of Health Behaviours}

Several previous studies have emphasised the importance of social and environmental determinants of behaviour as well as healthy health outcomes (Croezen, Picavet, Haveman-Nies, Verschuren, De Groot \&Van'T Veer, 2012; Carlson et al., 2012; White, Philogene, Fine, \& Sinha, 2009; Popkin, 2009; Shaikh, Yaroch, Nebeling, Yeh, \& Resnicow, 2008; Wendel-Vos, Droomers, Kremers, Brug \& Van Lenthe, 2007; Brownson, Baker, Housemann, Brennan, \& Bacak, 2001; Kahn, et al., 2002; Eyler, Brownson, Donatelle, King, Brown \& Sallis, 1999). Krishnan et al. (2015) also supported that the assess on social, cultural and behavioural factors may influence NCD control. According to Baron et al. (2014) argued that social-ecological models are able to provide a good understanding in comprehending the influences that can affect health outcomes to reduce health inequality among low-income workers.

Thus, this paper adopted the Social-Ecological Model of Health Behaviour by McLeroy et al. (1988) related to health behaviours and health promotion. It consists of five sources of influence from various levels including intrapersonal factor, interpersonal factor, organisational factor, community factor and societal factor. According to Centre for Diseases Control (2002), SEM model is a comprehensive model that integrates various levels of interrelated influences (dynamic transactions) within the scope of human environmental life in helping to determine one's health behaviour. In light of these studies, theories such as the SEM can be potentially used as a framework guide in explaining NCD prevention behaviour among low-income workers.

\section{Potential of Factors to Prevent Chronic Diseases Intrapersonal Factor}

Intrapersonal factors represent knowledge, attitudes, personality, beliefs and skills (Golden \& Earp, 2012; McLeroy et al., 1988). Based on this view, only the relevant intrapersonal factors (i.e., knowledge) from the McLeroy's model of SEM (1988) was incorporated in this research framework.

\section{Knowledge}

Knowledge is the foundation of the human thoughts (Fiesbein \& Ajzen, 1975). It serves as the core on determining attitudes, intentions and behaviours (Mahmud \& Siarap, 2013). This is supported by Mahadevan (2009) and Valente et al. (1998) stated that if one's knowledge is increased, that knowledge will be the impetus for a change of attitude. Past studies have shown a significant 
relationship between knowledge, environment, attitudes and awareness on diabetes (Latif, Hamid \& Abidin, 2018). Ithnin et al. (2019) also reported a good result on knowledge (81.2\%) among the adult population in the urban area of Negeri Sembilan. Thus, it can be stated that knowledge of health helps empowering individuals for improving healthcare and disease prevention.

\section{Interpersonal}

Interpersonal relationships can be referred to as close relationships that occur between two or more individuals (Heider 1958). It involves relationships such as family, friends and partners. According to Taechaboonsermsak et al. (2005) stated that social support can influence health-related behaviours. Previous studies have shown that the formal support of companies and tacit support of the family affect employees' health and health (Allen, 2001). Family and community relationships have also influenced jobs where this social support helps motivate employees to adapt to a change in chronic diseases (Vooijs, Leensen, Hoving, Wind \& Frings-Dresen, 2017; Kaşikçi, June \& Alberto, 2007). Furthermore, the social support of co-workers and occupational managers contributes to enhancing employee motivation and health by reducing pain stress and job failure (Nilsson, Fitinghoff \& Lilja, 2007; Lacaille, Green, Backman \& Gignac, 2007; Banks \&Lawrence,2006; Lacaille, Sheps, Spinelli, Chaltmers \& Esdaile, 2004; Detaille, Haafkens \& Van Dijk, 2003). According to Nilsson, Fitinghoff and Lilja (2007); Banks and Lawrence (2006); Detaille, Haafkens and Van Dijk, (2003), the work culture supported and taken care of by management, and colleagues are able to retain employees. This is because, by fostering trust and mutual support between workers, social support tends to attract employees and motivates employees to become more relaxed, while the support for relationships with subordinates has a subjectively beneficial effect on individuals and well-being (Chou, 2015).

\section{Organizational}

Studies demonstrated that at the organizational level, the comfortable nature of the workplace (environment) can increase employees' motivation in performing physical activities, whereas welfare in the workplace influences the behaviour of doing physical activities positively (Mohadis, Ali, \& Shahar, 2016). In addition, several studies have also reported that the provision of facilities and accessibility of equipment in the workplace produced the result of weight control reduction among employees (Ball, Timperio, \& Crawford, 2006; Cornelisse-Vermaat, Antonides, Van Ophem \& Van Den Brink, 2006: Duncan, Spence, \& Mummery, 2005; Diane, Ebert, Ngamvitroj, Park, \& Kang, 2004). Coats and Lekhi (2008) found that physical and psychological well-being programs can have an impact on productivity, attendance and employee commitment. Meanwhile, studies supported that smoking should not be allowed in malls and workplaces (Hock et al., 2017).

\section{Community}

The approach of health programs in a community has been observed able to increase knowledge as well as change the perceptions and attitudes about the awareness of NCD. Bauer, Briss, Goodman and Bowman (2014) supported this by stating that such public programs can provide knowledge and skills especially to those suffering from chronic diseases for managing their health condition better. Meanwhile, Trisnowati, Rodiyah \& Marlinawati (2016) asserted that community intervention program strategies are capable of empowering communities to change their behaviour and control NCD risk factors. This is because there are still many people who do not realise that they have NCD 
INTERNATIONAL JOURNAL OF ACADEMIC RESEARCH IN BUSINESS AND SOCIAL SCIENCES

Vol. 10, No. 16, Youth and Community Wellbeing: Issues, Challenges and Opportunities for Empowerment V2. 2020, E-ISSN: 2222-6990 @ 2020 HRMARS

and are at risk of NCD. Therefore, community involvement efforts are an effective strategy to prevent various risk factors at an earlier stage (Jayadipraja, Prasetya, Azlimin \& Mando, 2018).

In addition, other roles are played by stakeholders such as religious parties, social service agencies to help community in influencing health behaviour by providing service facilities such as recreational places, public parks, programs as well as welfare and safety centres (Wendel-Vos et al., 2007). In addition, study revealed that the built environment such as walking paths in the neighbourhood was considered to have a value of its own attribute to the population (Owen, Humpel, Leslie, Bauman \& Sallis, 2004). Also, the provision of infrastructure facilities such as supermarkets and grocery stores through the sales and promotions of healthy food products in the market encouraged people to adopt a healthy diet (Palmer, Winham, Oberhauser \& Litchfield, 2018).

\section{Societal}

Roles and support are needed in preventing and controlling NCDs with comprehensive collaboration from government, private, non-governmental organisations (NGOs), community as well as social leaders. In Malaysia, the implementation of the National Strategic Plan for Non-Communicable Diseases (NSP-NCD) 2016-2025 is one of the frameworks of an integrated plan to address NCD risk factors involving joint ventures of all parties including Ministry of Health of Malaysia (MOH), private sectors, NGOs and the public. Studies showed that the government's initiative in reducing the prevalence of smoking through the implementation of increased cigarette tax in 2015 from $42.03 \%$ to $49.4 \%$ is expected to reduce the prevalence of smoking by $27.5 \%$ in 2020 and $54.9 \%$ in 2055 (Nor et al., 2018). Also, the National Plan of Action for Nutrition of Malaysia (NPANM) III is one of the programs or initiatives in the NSP-NCD 2016-2025 in implementing the plan or need to prevent and control NCD related to diet as a result of the issue of overweight and obesity in the society (Goh, Azam-Ali, McCullough \& Mitra, 2020).

In addition, mass media have been proven able to channel and disseminate useful information to the community. Randolph and Viswanath (2004) claimed that the mass media is a recognised channel in the society, which serves as the main source in disseminating information to the public. Several previous studies have demonstrated that the mass media can influence knowledge, attitudes, motivations, self-efficacy as well as beliefs and cognition of health behaviour (Bandura et al., 2000; Rhodes 2016; Wong 2016). Also, finding the information about behaviour through websites is considered important as the latest information channels that can be helpful and reliable (MCMC, 2017). Other studies showed that the use of the Internet provides useful benefits as well as a good attitude towards the search for health information (Ahadzadeh \& Sharif, 2017). Also, it has been acknowledged that mass media campaigns including newspapers and other printed materials, radio, television and billboards are the main source of health information at individual level (Randolph et al., 2004). This is also supported by Buller et al. (2011) where newspapers still serve as an important source of information to the public in providing information in the form of public debates on various issues including health such as tobacco control. 


\section{Attitude as Mediator}

Attitude was chosen as a mediating variable between the independent variables and dependent variable. Attitude has been examined as a motivator for a person to increase their motivation to behave. For example, researcher (e.g., Park, Buist, Tiro, \& Taplin, 2008) has reported attitude (believing mammography is beneficial) mediates the relationship between annual household income and mammogram receipt among women. A study involving sample of older adults by (Trigg, Watts, Jones, Tod \& Elliman, 2012) found that moderate correlations between attitudes toward psychosocial loss and capacities for activities of daily living upon the quality of life (QOL). Similarly, An et al. (2016) showed that attitude has a positive full mediating effect on the relationship between knowledge of tuberculosis prevention screening and tuberculosis prevention behavior. Meanwhile, the study by Wood et al. (2014) in measuring behavioural intentions and evaluating the mediation of attitude achievement among university staff and students has shown attitude accessibility as an important mediator on the relationship between intention and behavioural measurement. In another study in Thailand, Saengcha, Pattanapongthorn and Jermsittiparsert (2019) examined the influence of attitude mediator between beliefs and intentions on the use of e-health system among health practitioners, showing that beliefs contributed $24.76 \%$ variance $(R 2=0.2476)$ to intentions when the role of attitudes interacted. Thus, based on previous studies, this article revealed that attitude is important as a mediator to improve effective behaviour and disease management.

\section{Conceptual Framework}

Based on the SEM model and empirical evidences obtained from literature reviews, this article attempts to predict several factors and attitude as mediators in influencing NCD disease prevention behaviour among low-Income workers.

The framework of this article illustrates the five groups of variables. The group variables are intrapersonal factor, interpersonal factor, organizational factor, community factor and societal factor factors. The intrapersonal factor include knowledge. The interpersonal factors include family, friends and health team. The organizational factor include workplace. The community factors include neighbourhood, local community and community organization. The societal factors include policy and mass media.

This article proposed (i.e., attitude) as a mediating variable for the relationship between the independent variables (i.e., knowledge, family, friends and health team, workplace neighbourhood, local community and community organization policy and mass media) and the dependent variable (i.e., prevention-related practice behaviors). Therefore, this study enhances McLeroy et al.'s (1988) model of SEM by integrating intrapersonal factor, interpersonal factor, organizational factor, community factor, societal factors and attitude as a mediating variable (as shown in Figure 1). 


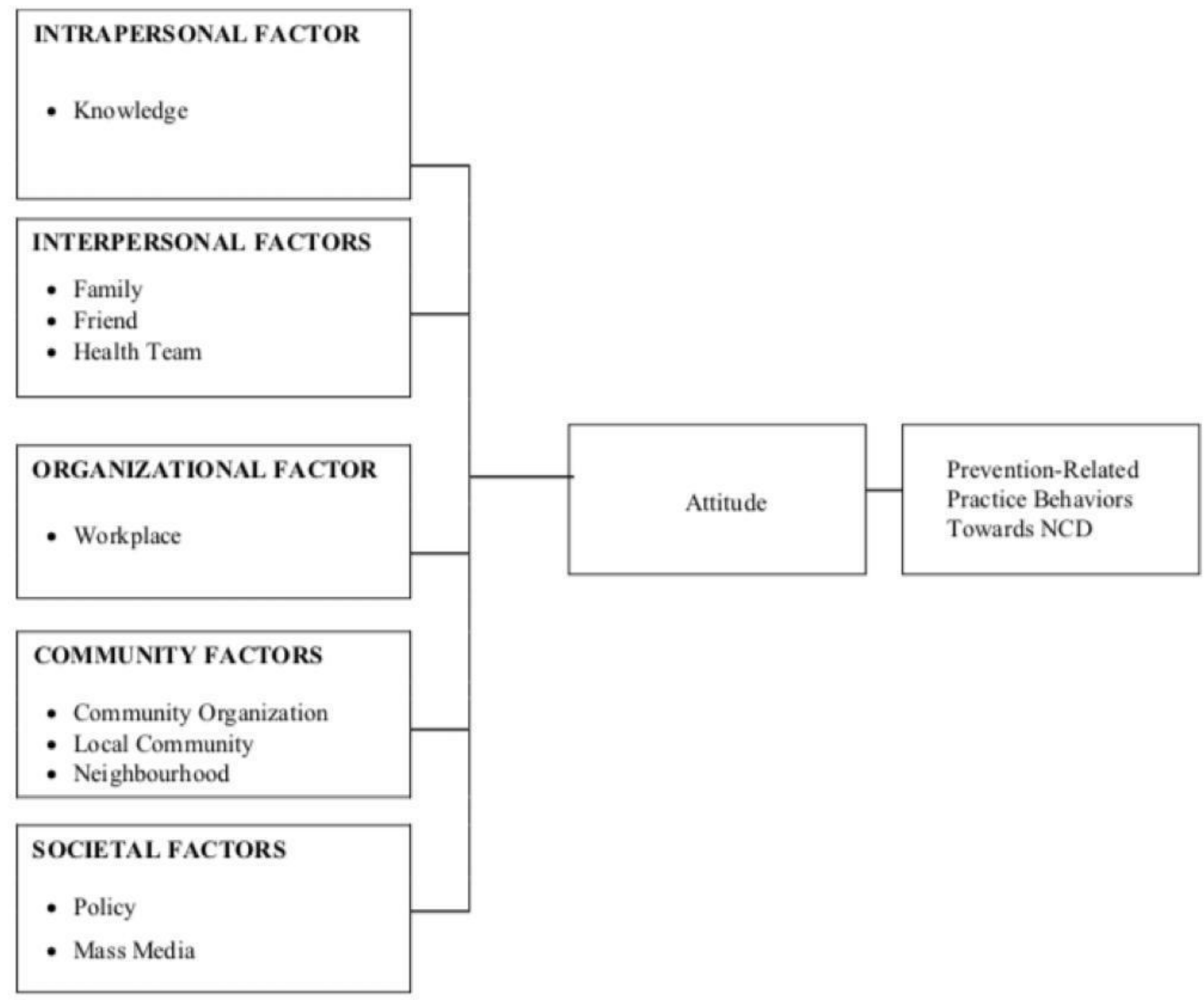

Figures 1: Conceptual Framework

\section{Conclusion and Recommendations}

Given that NCD at work has a health impact on low-income workers and a financial burden on individuals, families, organization and countries, the need of study in identifying the influence of practice behaviors of employees related to the prevention of NCD should be considered by involving the influence of various factors or multi-dimensional interactions for providing a clearer explanation of the influence of these factors. Therefore, this paper recommended that confirmation on the strength of the proposed relationship prediction between sets of variables should be made in future studies. In addition, this proposed research framework can develop intervention which leads to multi-level suggestions to existing employee health programs especially to low-income workers. 


\section{References}

Ahadzadeh, A. S., \& Sharif, S. P. (2017). Online Health Information Seeking among Malaysian Women: Technology Acceptance Model Perspective. The Journal of the South East Asia Research Centre for Communications and Humanities, 9(1): 47-70.

Allen, T. D. (2001). Family-supportive work environments: the role of organizational perceptions. Journal of Vocational Behavior, 58(3):414-435.

Amal, N. M., Paramesarvathy, R., Tee, G. H., Gurpreet, K., \& Karuthan, C. (2006). Prevalence of Chronic Illness and Health Seeking Behaviour in Malaysian Population: Results from the Third National Health Morbidity Survey (NHMS III) 2006. Medical Journal of Malaysia, 66 (1): 36-41.

An, H. G., Ha, J. Y., \& Kim, S. H. (2016). Mediating Effect of Attitude on the Relationship between Knowledge about Tuberculosis and Preventive Behavior Toward Tuberculosis of Foreign Students. International Journal of Bio-Science and Bio-Technology, 8(2): 181-196.

Ball, K., Timperio, A. F., \& Crawford, D. A. (2006). Understanding environmental influences on nutrition and physical activity behaviors: Where should we look and what should we count? International Journal of Behavioral Nutrition and Physical Activity, 3(33): 18.

Bandura A. (2000). Exercise of human agency through collective efficacy. Current Directions in Psychological Science, 9(3):75-78.

Banks, P., \& Lawrence, M. (2006). The Disability Discrimination Act, a necessary, but not sufficient safeguard for people with progressive conditions in the workplace? The experiences of younger people with Parkinson's disease. Disability and Rehabilitation, 28: 13-24.

Baron, S. L., Beard, S., Davis, K., Delp, L., Forst, L., Kidd-Taylor, L., Liebman, A., K., Linnan, A., Punnett, L., Welch, L. S. (2014). Promoting Integrated Approaches to Reducing Health Inequities Among Low-Income Workers: Applying a Social Ecological Framework. American Journal of Industrial Medicine, 57: 539-556.

Bauer, U. E., Briss, P. A., Goodman, R. A., \& Bowman, B. A. (2014). Prevention of chronic disease in the $21^{\text {st }}$ century: elimination of the leading preventable causes of premature death and disability in the USA. Lancet, 5,384(9937): 45-52.

Brownson, R. C., Baker, E. A., Housemann, R. A., Brennan, L. K., \& Bacak, S. J. (2001). Environmental and policy determinants of physical activity in the United States. American Journal of Public Health, 91(12): 1995-2003.

Buller, D. B., Bettinghaus, E. P., Helme, D., Young, W. F., Borland, R., Maloy, J. A., Cutter, G. R., Andersen, P. \& Walther, J. B. (2011). Supporting tobacco control: Stimulating local newspaper coverage with a technical assistance website for local coalitions. Health Promotion Practice, 12(6): 186-195.

Carlson, J. A., Sallis, J. F., \& Conway, T. L., Saelens, B. E., Frank, L. D., Kerr, J., Cain, K. L., King, A. C. (2012). Interactions between psychosocial and built environment factors in explaining older adults' physical activity. Preventive Medicine, 54(1): 68-73. 
Chan, C. M. H., Wong, J. E., Yeap, L. L. L., Wee, L. H., Jamil, N. A., \& Nantha, Y. S. (2019). Workplace bullying and psychological distress of employees across socioeconomic strata: a cross-sectional study. BMC Public Health, 19(4): 608.

Chou, P. (2015). The Effects of Workplace Social Support on Employee's Subjective WellBeing. European Journal of Business and Management, 7(6): 8-19.

Coats, D. M., \& Lehki, R., (2008). Good Work': Job Quality in a Changing Economy, London: The Work Foundation.

Cornelisse-Vermaat, J. R., Antonides, G., Van Ophem, J. A. C., \& Van Den Brink, H. M. (2006). Body mass index, perceived health, and happiness: Their determinants and structural relationships. Social Indicators Research, 79: 143-158.

Croezen, S., Picavet, H. S. J., Haveman-Nies, A., Verschuren, W. M., De Groot L. C., Van'T Veer, P. (2012). Do positive or negative experiences of social support relate to current and future health? Results from the Doetinchem Cohort Study. BMC Public Health, 12(65): 2-8.

Detaille, S. I., Heerkens, Y. F., Engels, J. A., Van Der Gulden, J. W., \& van Dijk, F. J. (2013). Effect evaluation of a self-management program for dutch workers with a chronic somatic disease: A randomized controlled trial. Journal of Occupational Rehabilitation, 23: 189-199.

Diane, V. A., Ebert, S., Ngamvitroj, A., Park, N., \& Kang, D. H. (2004). Predictors of health behaviors in college students. Journal of Advanced Nursing, 48: 463-474.

Duncan, M. J., Spence, J. C., \& Mummery, W. K. (2005). Perceived environment and physical activity: A meta-analysis of selected environmental characteristics. International Journal of Behavioral Nutrition and Physical Activity, 2(11): 1-9.

Eyler, A. A., Brownson, R. C., Donatelle, R. J., King, A. C., Brown, D., \& Sallis, J. F. (1999). Physical activity social support and middle- and older-aged minority women: results from a US survey. Social Science and Medicine, 49(6): 781-789.

Eng, J. Y., Moy, F. M., \& Bulgiba, A. (2016). Impact of a Workplace Health Promotion Program on Employees' Blood Pressure in a Public University. PLoS ONE, 11(2): 1-14.

Fiidow, O. A., Huda, B. Z., \& Salmiah, M. S. (2016). Socio-demographic Factors of Hypertension among Non-Academic Staff in Universiti Putra Malaysia. International Journal of Public Health and Clinical Sciences, 3 (4): 158-168.

Fishbein, M., \& Ajzen, I. (1975). Belief, Attitude, Intention and Behavior: An Introduction to Theory and Research, New York: Addison-Wesley Publishing Company.

Goh, E. V., Azam-Ali, S., McCullough, F., \& Mitra, S. R. (2020). The nutrition transition in Malaysia; key drivers and recommendations for improved health outcomes. BMC Nutrition 6(32): 2-14.

Golden, S. D., \& Earp, J. A. L. (2012). Social Ecological Approaches to Individuals and Their Contexts: Twenty Years of Health Education \& Behavior Health Promotion Interventions. Health Education \& Behavior, 39 (3): 364-372.

Grosch, J. W., Alterman, T., Petersen, M. R., Murphy, L. R. (1988). Worksite health promotion programs in the U.S.: factors associated with availability and participation. American Journal of Health Promotion, 13(1): 36-45.

Heider, F. (1958). The psychology of interpersonal relations: John Wiley \& Sons, Inc. 
Hock, L. K., Li, L. H., Huey, T. C., Yuvaneswary, V., Sayan, P., Yusoff, M. F. M., Kuay, L. K., Yn, L. M., Chee, C. K., \& Mohd, G. S. (2017). Support for smoke-free policy among Malaysian adults: findings from a population-based study. BMJ Open, 9(e020304).

Iordanides, G. D., Bakas, T., Saiti, A. C., \& Ifanti, A. A. (2014). Primary Teachers' and Principals' Attitudes towards Conflict Phenomenon in Schools in Greece. Multilingual Academic Journal of Education and Social Sciences, 2(2), 30-52.

Ithnin, M., Nor N. A. U. M., Juliana, N., Effendy, N. M., Sahar, M. A., Abdullah, K. H. A., Aris, M. S. M., Rani, M. D. M. (2019). Knowledge, attitude, and practice on NonCommunicable Diseases (NCDs) among the adult population in the urban area of Negeri Sembilan, Malaysia. International Journal of Research in Pharmaceutical Sciences, 9(SPL2): 88-94.

Jayadipraja, E. A., Prasetya, F., Azlimin, Mando, W. O. S. Y. (2018). Family Clean and Healthy Living Behavior and Its Determinant Factors in The Village of Labunia, Regency of Muna, Southeast Sulawesi Province of Indonesia. Public Health of Indonesia, 4(1): 3945.

Kahn, E. B., Ramsey, L. T., Brownson, R. C., Heath, G. W., Howze, E. H., Powell, K. E., Stone, E. J., Rajab, M. W., Corso. P. (2002). The effectiveness of interventions to increase physical activity. A systematic review. American Journal of Preventive Medicine, 22(4): 73-107.

Kaşikçi, M. K., \& Alberto, J. (2007). Family support, perceived self-efficacy and self-care behaviour of Turkish patients with chronic obstructive pulmonary disease. Journal of Clinical Nursing, 16(8): 1468-78.

Keenan, P. S. (2009). Smoking and weight change after new health diagnoses in older adults. Archives of Internal Medicine, 169(3): 237-242.

Krishnan, S., Sivaram, S., Anderson, B. O., Basu, P., Belinson, J. L., Bhatla, N., Cruz, A. D., Dhillon, P. K., Gupta, P. C., Joshi, N., Jhulka, P. K., Kailash, U., Kapambwe, S., Katoch, V. M., Kaur, P., Kaur, T., Mathur, P., Prakash, A., Sankaranarayanan, R., Selvam, J. M., Seth, T., Shah, K. V., Shastri, S., Siddiqi, M., Srivastava, A., Trimble, E., Rajaraman, P., \& Mehrotra, R. (2015). Using implementation science to advance cancer prevention in India. Asian Pacific Journal of Cancer Prevention, 16(9): 3639-3644.

Lacaille, D., Sheps, S., Spinelli, J. J., Chalmers, A., \& Esdaile, J. M. (2004). Identification of modifiable work-related factors that influence the risk of work disability in rheumatoid arthritis. Arthritis \& Rheumatology, 51: 843-852.

Lacaille, D., White, M. A., Backman, C. L., \& Gignac, M. A. (2007). Problems faced at work due to inflammatory arthritis: new insights gained from understanding patients' perspective. Arthritis \& Rheumatology Arthritis, 57: 1269-1279.

Latif, H. A., Hamid, M. R. A., \& Abidin, N. A. Z. (2018). Awareness of Diabetes Mellitus Among Public Attending the Primary Health Centers in Malaysia. Journal of Quality Measurement and Analysis, 14(2): 11-23.

Lee, M., Park, S., \& Lee, K. S. (2020). Relationship between Morbidity and Health Behavior in Chronic Diseases. Journal of Clinical Medicine, 9(1): 2-11.

Mansor, M. R. A., Kassim, K. A. A., \& Jawi, Z. M. (2020). Willingness to Purchase Safer Vehicles: A Study Base on Malaysia B40 Income Group. Jurnal Kejuruteraan, 3(1): 71-74. 
Mahmud, M. H., \& Siarap, K. (2013). Kempen Pencegahan H1N1: Kajian Tentang Pengetahuan, Sikap Dan Amalan Penduduk Di Timur Laut Pulau Pinang. Jurnal Komunikasi Malaysian, 29(1): 127-140.

MCMC. (2017). Internet Users Survey 2017. Malaysian Communications and Multimedia Commission; Cyberjaya, Malaysia.

McLeroy, K. R., Bibeau, D., Steckler, A., \& Glanz, K. (1988). An ecological perspective on health promotion programs. Health Educ Q. Winter, 15(4): 351-77.

Mohadis, H. M., Ali, N. M., \& Shahar, S. (2016). Motivators and Barriers for Physical Activity in Older Workers: A Socio-Ecological Exploration. Malaysian Journal of Public Health Medicine, 16(3): 261-266.

Nilsson, I., Fitinghoff, H., \& Lilja, M. (2007). Continuing to work after the onset of rheumatoid arthritis. Work, 28: 335-342.

Nor, N. M., Ross, H., Thinng, W. B. K., Ghani, J. A., Hassan, N., \& Baharom, N. (2018). Malaysia Abridged SimSmoke Model - Towards Achieving 2025 and 2045 Smoking Prevalence Targets. Malaysian Journal of Medicine and Health Sciences, 14(3): 8-15.

Othman, Z., Aleem, N. A. A., Ramli, M. D. C., Sariman, S., Harun, H., Rahman, M. A., Daud, S. M. S. M., Baharudin, H. (2020). Knowledge, Awareness and Practices on the Risk Factors of Cardiovascular Diseases Among Community in Gombak, Kuala Lumpur. Malaysian Journal of Medicine and Health Sciences, 6(1): 72-81.

Ozminkowski, R. J., Goetzel, R. Z., Wang, F. Gibson, T. B., Shechter, D., Musich, S., Bender, J., \& Edington, D. W. (2006). The savings gained from participation in health promotion programs for medicare beneficiaries. Journal of Occupational and Environmental Medicine, 48(11): 1125-1132.

Owen, N., Humpel, N., Leslie, E., Bauman, A., Sallis, J. F. (2004). Understanding Environmental Influences on Walking: Review and Research Agenda". American Journal of Preventive Medicine, 27: 67-76.

Park, A. N., Buist, D. S. M., Tiro, J. A., \& Taplin, S. H. (2008). Mediating Factors in the Relationship between Income and Mammography Use in Low-Income Insured Women. Journal of Women's Health, 17(8): 1371-1378.

Palmer, S. M., Winham, D. M., Oberhauser, A. M., \& Litchfield, R. E. (2018). Socio-Ecological Barriers to Dry Grain Pulse Consumption among Low-Income Women: A Mixed Methods Approach. Nutrients 10, 1108:2-13.

Popkin, B. M. (2009). What can public health nutritionists do to curb the epidemic of nutrition-related non-communicable disease? Nutrition Reviews, 67(1): 79-S82.

Randolph, W., \& Viswanath, K. (2004). Lessons learned from public health mass media campaigns: marketing health in a crowded media world. Annual Review of Public Health, 25: 419-437.

Rani, M. D. M., Ithnin, M., Nor, N. A. U. M., Juliana, N., Effendy, N. M., Azmani, S., Abdullah, K. H. A., Aris, M. S. M., \& Abu, I. F. (2019). Comparison of health-seeking behaviour between urban and rural malay population of Negeri Sembilan, Malaysia. International Journal of Research in Pharmaceutical Sciences, 10(4): 3608-3615. 
Rockefeller Institute. Health Vulnerabilities of informal workers. (2013). Retrieved from https://assets.rockefellerfoundation.org/app/uploads/ 20130528214745/HealthVulnerabilities-ofinformal-Workers.pdf.

Rhodes, S. D., McCoy, T. P., Tanner, A. E., Stowers, J., Bachmann, L. H., Nguyen, A. L., \& Ross, M. (2016). Using social media to increase HIV testing among gay and bisexual men, other MSM, and transgender persons: outcomes from a randomized community trial. Clinical Infectious Diseases, 62(11): 1450-1453.

Saengcha, S., Pattanapongthorn, J., \& Jermsittiparsert, K. (2019). Influence of Beliefs on Attitudes and Intention of Adopting e-Health System among the Public Hospitals of Thailand. International Journal of Innovation, Creativity and Change, 8(8): 238-255.

Shahar, S., Lau, H., Puteh, S. E. W., Amara, S., \& Razak, N. A. (2019). Health, access and nutritional issues among low-income population in Malaysia: introductory note. $B M C$ Public Health, 19(4): 552,2-5.

Shaikh, A. R., Yaroch, A. L., Nebeling, L., Yeh, M. C., Resnicow, K. (2008). Psychosocial predictors of fruit and vegetable consumption in adults. A review of the literature. American Journal of Preventive Medicine, 34(6): 535-543.

Sherina, M. S., Rampal, L., Hejar, A. R., Rozali, A., \& Yunus, M. A. (2011). Prevalence of Urban Poor and Its Health Related Factors in the State of Selangor, Malaysia. Malaysian Journal of Medicine and Health Sciences, 7(1): 17-25.

Stringhini, S., Carmeli, C., Jokela, M., Avendaño, M., Muennig, P., Guida, F., Ricceri, F., d'Errico, A., Barros, H., Bochud, M., Chadeau-Hyam, M., Clavel-Chapelon, F., Costa, G., Delpierre, C., Fraga, S., Goldberg, M., Giles, G. G., Krogh, V., Kelly-Irving, M., Layte, R., Lasserre, A. M., Marmot, M. G., Preisig, M., Shipley, M.J., Vollenweider, P., Zins, M., Kawachi, I., Steptoe, A., Mackenbach, J. P., Vineis, P., Kivimaki, M., \& for the LIFEPATH consortium. (2017). Socioeconomic status and the $25 \times 25$ risk factors as determinants of premature mortality: a multicohort study and meta-analysis of 1.7 million men and women. The Lancet, 389(10075): 1229-12237.

Taechaboonsermsak, P., Kaewkungwal, J., Singhasivanon, P., Fungladda, W., \& Wilailak, S. (2005). Causal relationship between health promoting behavior and quality of life in cervical cancer patients undergoing radiotherapy. Southeast Asian Journal of Tropical Medicine and Public Health. 36(6): $1568-75$.

Trigg, R., Watts, S., Jones, R., Tod, A., \& Elliman, R. (2012). Self-reported quality of life ratings of people with dementia: the role of attitudes to aging. Psychogeriatrics, 24: 10851093.

Trisnowati, H., \& Rodiyah, Marlinawati, V. U. (2016). Prevention of Risk Factors for NonCommunicable Diseases through Community Empowerment (Case in A Rural Communities of Yogyakarta). 1st ICGH International Conference on Global Health, Jakarta, Indonesia.

Twardella, D., Loew, M., Rothenbacher, D., Stegmaier, C., Ziegler, H., \& Brennan, M. (2006). The diagnosis of a smoking-related disease is a prominent trigger for smoking cessation in a retrospective cohort study. Journal of Clinical Epidemiology, 59(1): 8289. 
Van Gool, C. H., Kempen, G. I., Penninx, B. W., Deeg, D. J., \& van Eijk, J. T. (2007). Chronic disease and lifestyle transitions: Results from the Longitudinal Aging Study Amsterdam. Journal of Aging and Health, 19(3): 416-438.

Vooijs, M., Leensen, M. C. J., Hoving, J. L., Wind, H. \& Frings-Dresen, M. H. W. (2017). Value of work for employees with a chronic disease. Occupational Medicine, 68: 26-31.

Wendel-Vos, W., Droomers, M., Kremers, S., Brug, J., Van Lenthe, F. (2007). Potential environmental determinants of physical activity in adults: a systematic review. Obesity Reviews, 8(5): 425-440.

White, A. M., Philogene, G. S., Fine, L., \& Sinha, S. (2009). Social support and self-reported health status of older adults in the United States. American Journal of Public Health, 99(10): 1872-1878.

Wilkinson, D., \& McDougall, R. (2007). Primary trauma care. Anaesthesia, 62(1): 61-64.

Wong, C. A., Ostapovich, G., Kramer-Golinkoff, E., Griffis, H., Asch, D. A, \& Merchant, R. M. (2016). How US children's hospitals use social media: a mixed methods study. Healthcare, 4(1): 15-21.

Yamada, M., Hapsari, E. D., \& Matsuo, H. (2020). Behaviors toward Noncommunicable Diseases Prevention and Their Relationship with Physical Health Status among Community-dwelling, Middle-aged and Older Women in Indonesia. 